28 days of onset of symptoms, were reported. Residual paralysis was found in only four cases of paralytic poliomyelitis occurring between 5 and 28 days after vaccination, an incidence of 1 in four and a half million doses administered. Three of the four were infants: there was no evidence, as in the United States, of a higher incidence in adults. No particular vaccine batches were implicated. Studies of the age, sex, and geographical distribution of cases and of their vaccination histories did not reveal any important differences between vaccine-associated and other cases. It is considered unlikely that disease was caused by spread of vaccine virus to contacts of vaccinated persons.

Type 3 poliovirus was isolated proportionately more often from vaccine-associated than from other cases, but this finding was not unexpected after administration of vaccine containing all three virus types. The frequency of isolation of poliovirus from other cases of paralytic poliomyelitis fell between 1962 and 1963-4, suggesting that a greater proportion of cases diagnosed as poliomyelitis in the later years may not have been due to infection with poliovirus.

It is concluded that the risk, if any, of the vaccine causing serious disease was extremely small, and, in view of the benefits conferred by vaccination, it did not justify any change in the present recommendations for the use of oral (Sabin) vaccine.
We are indebted to the many medical officers of health, hospital clinicians, general practitioners, and virologists who have co-operated in providing information concerning their patients, and to the Ministry of Health for the statistics on the use of oral vaccine.

\section{REFERENCES}

Conybeare, E. T. (1964). Mth Bull. Minist. Hlth Lab. Serv., 23, 126, $150,182$.

Galbraith, N. S. (1963). Proceedings of the Ninth Symposium of the European Association Against Poliomyelitis and Allied Diseases, Stockholm.

(1965). F. Hyg. (Lond.). In press.

Geffen, T. J. (1960). Mth. Bull. Minist. Hlth. Lab. Serv., 19, 196.

- and Spicer, C. C. (1960). Lancet, 2, 87.

Gelfand, H. M., Holguin, A. H., Marchetti, G. E., and Feorino, P. M. (1963). Amer. F. Hyg., 78, 358.

Henderson, D. A., Witte, J. J., Morris, L., and Langmuir, A. D. (1964), 7. Amer. med. Ass., 190, 41 .

Nathanson, N., and Langmuir, A. D. (1963). Amer. F. Hyg., 78, 16.

Public Health Laboratory Service (1962). Brit. med. F., 2, 142.

Roden, A. T. (1964). Proc. roy. Soc. Med., 57, 464.

Stuart-Harris, C. H. (1964). Ibid., 57, 459.

Special Advisory Committee to the Surgeon General of the Public Health Service (1964). F. Amer. med. Ass., 190, 49.

Terry, L. L. (1962). The association of cases of poliomyelitis with the use of type 3 oral poliom
Dept. Hith Educ. Welfare.

\title{
Effect of Treatment of Thyrotoxicosis on Exophthalmos
}

\author{
W. R. GREIG, * M.D., M.R.C.P.ED. ; S. A. ABOUL-KHAIR, † M.B., PH.D., D.C.H. ;
}

S. D. MOHAMED $\ddagger$ M.B., M.R.C.P., M.R.C.P.ED. ; J. CROOKS,§ M.D., F.R.C.P.ED., F.R.C.P.GLASG., M.R.C.P.

Brit. med. F., 1965, 2, 509-510

It is known that the treatment of thyrotoxicosis tends to increase the degree of exophthalmos (Werner, Coelho, and Quimby, 1957 ; Werner, 1961 ; Scholz, Haines, and Henderson, 1962 ; Trotter, 1962). Clinical impressions suggest that there may be an inverse relation between the rate of control of symptoms and this increase, but objective evidence for this view is lacking. In the present investigations we have studied the changes in exophthalmos associated with differing rates of control in thyrotoxic patients treated with antithyroid drugs and radioactive iodine.

\section{Material and Methods}

Selection of Patients.-Seventy-two untreated thyrotoxic patients were selected for study. All were investigated in hospital, and the diagnosis was made on clinical grounds (Crooks, Murray, and Wayne, 1959), serum protein-bound iodine (P.B.I.) estimations (Farrell and Richmond, 1961), and radioiodine studies (Macgregor and Wayne, 1958). None suffered from other associated organic disease, and all eventually

\footnotetext{
* Research Fellow, Department of Materia Medica and Therapeutics, University of Aberdeen. Present address : Department of Medicine, Royal Infirmary, Glasgow.

† Research Fellow, Department of Materia Medica and Therapeutics, University of Aberdeen.

¥ Senior Registrar and Clinical Tutor in Medicine, University Department of Materia Medica and Therapeutics and Royal Infirmary, Aberdeen.

$\$$ Reader, Department of Materia Medica and Therapeutics, University of Aberdeen.
}

responded satisfactorily to treatment. Mild-to-moderate exophthalmos was present in each case but none suffered from malignant exophthalmos. Forty-two of the patients were treated with radioiodine. The principles of selection, general management, and method of dose-prescription were similar to those of Macgregor (1957) and of Crooks, Buchanan, Wayne, and Macdonald (1960). Thirty patients were treated with methylthiouracil and received $600 \mathrm{mg}$. daily for the first two weeks of treatment and then $300 \mathrm{mg}$. daily till they were considered to be euthyroid.

Procedure.-Before treatment was started all patients had a standard clinical assessment carried out, the therapeutic index (T.I.) described by Crooks, Wayne, and Robb (1960) being used, and the degree of exophthalmos was measured by means of a Zeiss-Hertel exophthalmometer. After treatment with methylthiouracil was begun or radioactive iodine had been given, each patient was seen at intervals of two weeks, then monthly at an out-patient clinic. At each attendance the clinical response (T.I.), the serum P.B.I., and the exophthalmos were measured. A patient was regarded as euthyroid if the T.I. was five or less and the serum P.B.I. was within the normal range (3.4-7.2 $\mu \mathrm{g} . / 100 \mathrm{ml}$.) at two successive visits.

\section{Results}

The effect that the treatment of thyrotoxicosis has on the degree of exophthalmos is shown in Table I. The mean value of the exophthalmometric measurements (sum of both eyes) in 
the patients subsequently treated with methylthiouracil was 26.70 with a standard deviation of 4.39 , and was not significantly different from that found in the patients subsequently given radioiodine, 27.92, standard deviation $7.49(6.5>\mathrm{P}>0.4)$. The two groups were thus homogeneous in respect of this characteristic.

TABLE I.-Effect of Treating Thyrotoxicosis on Exophthalmometric Measurements

\begin{tabular}{|c|c|c|c|c|c|c|}
\hline \multirow[t]{2}{*}{ Treatment } & \multirow[t]{2}{*}{$\begin{array}{c}\text { No. } \\
\text { of } \\
\text { Cases }\end{array}$} & \multicolumn{2}{|c|}{$\begin{array}{c}\text { Exophthalmometric* } \\
\text { Measurement } \\
\text { before } \\
\text { Therapy }\end{array}$} & \multicolumn{2}{|c|}{$\begin{array}{l}\text { Exophthalmo- } \\
\text { metric* } \\
\text { Measurement } \\
\text { when Euthyroid }\end{array}$} & \multirow{2}{*}{$\begin{array}{l}\text { Comparison } \\
\text { between } \\
\text { Measure- } \\
\text { ments Before } \\
\text { and After } \\
\text { Therapy }\end{array}$} \\
\hline & & Mean \pm S.D. & S.E. & Mean & S.E. & \\
\hline $\begin{array}{l}\text { Methylthiouracil } \\
\text { Radioiodine .. }\end{array}$ & $\begin{array}{l}30 \\
42\end{array}$ & $\begin{array}{l}26 \cdot 70 \pm 4 \cdot 39 \\
27 \cdot 92 \pm 7 \cdot 49\end{array}$ & $\begin{array}{l}0 \cdot 80 \\
1 \cdot 16\end{array}$ & $\begin{array}{l}29 \cdot 43 \\
31 \cdot 05\end{array}$ & $\begin{array}{l}0.98 \\
1.03\end{array}$ & $\begin{array}{l}\mathrm{P}^{*}<0.001 \\
\mathrm{P}^{*}<0.001\end{array}$ \\
\hline
\end{tabular}

*.Sum of both eyes. P*, Paired t-test. S.D., Standard deviation

S.E., Standard error.

When the patients treated with methylthiouracil became euthyroid the mean degree of exophthalmos was $29.43 \pm 0.98$, while this value for the patients given radioiodine was $31.05 \pm 1.03$. Both these values were significantly higher than the respective pretreatment values $(P<0.001)$.

Of the 30 patients treated with methylthiouracil, the degree of exophthalmos diminished in one, did not change in five, and increased in 24 when they became euthyroid. Of the 42 patients treated with ${ }^{131} \mathrm{I}$ the degree of exophthalmos diminished in five, did not change in four, and increased in 33. Thus of the 72 patients 57 showed an increase in the degree of exophthalmos when the euthyroid state was achieved.

Comparison Between Rate of Control of Thyrotoxicosis by Methylthiouracil and Radioiodine.-Table II shows that of the 30 patients treated with methylthiouracil 19 became euthyroid within two months, 10 between two and four months, and only one required more than four months' treatment. In the 42 patients treated with radioiodine the time taken to become euthyroid was two months in 4 patients, between two and four months in 19, and more than four months in the remaining 19. Thus the rate of control of thyrotoxicosis was significantly more rapid with methylthiouracil than with radioiodine $(\mathbf{P}<0.001)$.

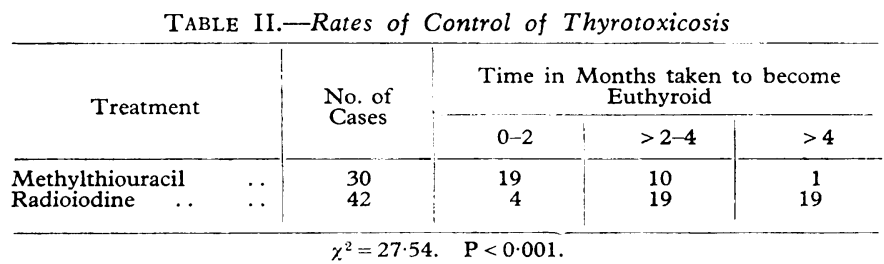

Change in Degree of Exophthalmos and Rate of Control.The changes in exophthalmos with differing rates of control are compared in Table III. In the group treated with methylthiouracil the mean increase in the exophthalmometric measurements was $2.76+0.65$ when the euthyroid state was reached. This was not significantly different $(0.7>\mathrm{P}>0.6)$ from the value of $3.09 \pm 0.47$ in the radioiodine-treated group, although they took longer to become euthyroid. When the patients given radioiodine were analysed separately 23 who became euthyroid

TABLE III.-Effect of Different Rates of Control of Thyrotoxicosis on

\begin{tabular}{|c|c|c|c|c|c|}
\hline \multirow[t]{2}{*}{ Treatment } & \multirow[t]{2}{*}{$\begin{array}{l}\text { No. } \\
\text { of } \\
\text { Cases }\end{array}$} & \multicolumn{2}{|c|}{$\begin{array}{l}\text { Algebraic Change in } \\
\text { Exophthalmometric } \\
\text { Measurements } \\
\text { when } \\
\text { Euthyroid }\end{array}$} & \multirow[t]{2}{*}{$\begin{array}{c}\text { Comparison } \\
\text { between } \\
\text { Measured } \\
\text { Changes }\end{array}$} & \multirow{2}{*}{$\begin{array}{c}\text { Correlation } \\
\text { between } \\
\text { Time to } \\
\text { become } \\
\text { Euthyroid } \\
\text { and Change } \\
\text { Exophthalmos }\end{array}$} \\
\hline & & Mean & S.E. & & \\
\hline \multirow{4}{*}{$\begin{array}{l}\text { Methylthiouracil .. } \\
\text { Radioiodine } \\
\text { Euthyroid within } \\
0-4 \text { months } \\
\text { Euthyroid within } \\
5 \text {-14 months.. }\end{array}$} & $\begin{array}{l}30 \\
42\end{array}$ & $\begin{array}{l}2.76 \\
3.09\end{array}$ & $\begin{array}{l}0.65 \\
0.47\end{array}$ & $0.7>\mathrm{P}>0.6$ & \multirow{4}{*}{$\begin{array}{l}r=0.073 \\
r=0.025\end{array}$} \\
\hline & & & & & \\
\hline & 23 & $3 \cdot 13$ & 0.59 & $P>0.9$ & \\
\hline & 19 & $3 \cdot 16$ & 0.91 & & \\
\hline
\end{tabular}

within four months showed a mean increase in exophthalmos $(3.13 \pm 0.59)$ which was not different from the increase $(3.16 \pm 0.91)$ shown by 19 patients who took between 5 and 14 months to become euthyroid $(\mathbf{P}>0.9)$. No correlation was found between the rate of control of thyrotoxicosis and the increase in exophthalmos with either type of treatment when correlation coefficients were derived $(r=0.073$ for the drugtreated group and $r=0.025$ for the ${ }^{131}$ I-treated group).

\section{Discussion}

Before any conclusions can be drawn regarding the effect of different forms and rates of treatment for thyrotoxicosis on exophthalmos two conditions must be satisfied: the patients should be homogeneous in respect of the degree of exophthalmos before treatment starts, and the treatment should produce a significant change in that measurement. Table I shows that both these conditions were satisfied in the present study.

The suggestion that thyrotoxicosis associated with exophthalmos should be controlled slowly to minimize the expected increase in the protrusion of the eyes has not been confirmed in the present study, and we are in agreement with Hamilton, Schultz, and de Gowin (1960) that there would appear to be no therapeutic advantage from a slow rate of control. It is of interest to note that Bartels and Irie (1961) found that the incidence of malignant exophthalmos did not increase after energetic antithyroid drug treatment.

It may be of aetiological importance in the causation of exophthalmos that the extent of the increase in protrusion of the eyes is a function of the return to the euthyroid state rather than the rate at which this is achieved. If exophthalmos is due to an exophthalmos-producing substance secreted by the pituitary (McGill, 1963) then this finding suggests that either the secretion or the peripheral action of this substance may be enhanced when the serum thyroxine level falls into the normal range irrespective of the rate of this fall.

\section{Summary}

In 72 thyrotoxic patients-30 treated with methylthiouracil and 42 with ${ }^{131} \mathrm{I}$ - the degree of exophthalmos was measured before and after control of the hyperthyroidism. Exophthalmos increased equally in both groups irrespective of the rate of control or type of treatment used. It is concluded that a rapid return to the euthyroid state in thyrotoxicosis will have no adverse effects on the degree of exophthalmos.

We are grateful to Professor A. G. Macgregor for allowing us to study patients under his care.

\section{REFERENCES}

Bartels, E. C., and Irie, M. (1961). In Advances in Thyroid Research, edited by R. Pitt-Rivers, p. 169 . Pergamon Press, London and Oxford.

Crooks, J., Buchanan, W. W., Wayne, E. J., and Macdonald, E. (1960). Brit. med. F., 1,151 .

Murray, I. P. C., and Wayne, E. J. (1959). Quart. F. Med., 28, 211. Wayne, E. J., and Robb, R. A. (1960). Lancet, 1, 397.

Farrell, Familton .' a. Schultz, R. O., and de Gowin, E. L. (1960). Arch. intern. Med., 105, 675 .

McGill, D. A. F. (1963). In The Thyroid and its Diseases, edited by A. S. Mason, p. 92. Pitman, London.

Macgregor, A. G. (1957). Brit. med. F., 1, 492.

- and Wayne, E. J. (1958). In Modern Trends in Endocrinology, edited by $H$. Gairdiner-Hili, p. 34 . Butterworth, London.

Scholz, D. A., Haines, S. F., and Henderson, J. W. (1962). Arch. intern. Med., 109, 526.

Trotter, W. R. (1962). Diseases of the Thyroid, pp. 53, 55, 90. Blackwell, Oxford.

Werner, S. C. (1961). f. Amer. med. Ass., 177, 551.

Coelho, B., and Quimby, E. H. (1957). Bull. N.Y. Acad. Med., 33, 783. 